\title{
Proliferation of human adipose tissue-derived stem cells stimulated by oil rich in thymol of Lippia origanoides ${ }^{1}$
}

Felipe Nunes Brito', Fabiel Spani Vendramin", Cinthia Távora de Albuquerque Lopes"', Mayra Pauline Ribeiro Costa'v, Otávio Mitio Ohashi", José Guilherme Soares Maiav', Lydia Masako FerreiraVII, Joyce Kelly do Rosário da Silva VIII, Moysés dos Santos Miranda'X

'MD, School of Medicine, Universidade Federal University do Pará (UFPA), Belem-PA, Brazil. Conception of the study, interpretation of data, technical procedures, manuscript preparation.

"Assistant Professor, Surgery Division, UFPA, Belem-PA, Brazil. Interpretation of data, critical revision.

"'MSc, UFPA, Belem-PA, Brazil. Technical procedures, interpretation of data.

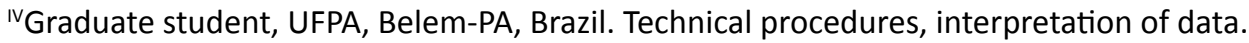

${ }^{\vee} \mathrm{PhD}$, Full Professor, Biomedicine Division, UFPA, Belem-PA, Brazil. Analysis and interpretation of data, critical revision.

V'PhD, Full Professor, Chemistry Division, Universidade Federal do Oeste do Pará (UFOPA), Santarem-PA, Brazil. Analysis and interpretation of data, critical revision.

VIIPhD, Head and Full Professor, Plastic Surgery Division, Universidade Federal de São Paulo (UNIFESP), Brazil. Analysis and interpretation of data, critical revision.

VIIIPhD, Assistant Professor, Biotechnology Division, UFPA, Belem-PA, Brazil. Conception of the study, statistical analysis, interpretation of data, critical revision.

${ }^{\mathrm{X} P h D}$, Assistant Professor, Biotechnology Division, UFPA, Belem-PA, Brazil. Conception of the study, analysis and interpretation of data, critical revision.

\section{Abstract}

Purpose: To evaluate the effects of this thymol-rich oil in the proliferation of human adipose tissue-derived stem cells.

Methods: Stem cells were isolated from human adipose tissue by liposuction After the first passage, cells were cultivated in triplicate for three days in control medium and medium supplemented with three oil samples $(1.0 \mu \mathrm{g} / \mathrm{mL}, 5.0 \mu \mathrm{g} / \mathrm{mL}$, and $25.0 \mu \mathrm{g} / \mathrm{mL})$. Cells were analyzed by the MTT assay at passage 1 (P1), and cell proliferation of control and $1 \mu \mathrm{g} / \mathrm{mL}$ groups was determined with a hemocytometer at P2 and P3.

Results: Viability of the essential oil-treated cells was significantly higher than the control group at P1 ( $p=0.0008$ ). The treatment with the oil, at a concentration of $1 \mu \mathrm{g} / \mathrm{mL}$, led to increases of $24.8 \%$ at P1 and $43.0 \%$ at P3 in the rate of cell proliferation compared with control cells.

Conclusion: Supplementing culture medium with essential oil of Lippia origanoides increased cell proliferation, especially at later passages.

Key words: Stem Cells. Adipose Tissue. Cell Proliferation. Thymol. 


\section{- Introduction}

The isolation of mesenchymal stem cell (MSC) from human adipose tissue obtained from liposuction was described in $2001^{1}$. Liposuction is one of most common esthetic surgical procedures worldwide, and it generates an average of $100-3000 \mathrm{~mL}$ of adipose tissue that is routinely discarded, along with its incorporated stem cells ${ }^{2}$. In addition to being easily obtained, adipose-derived stem cells (ADSCs) also have significant therapeutic use ${ }^{3}$, as an acute myocardial infarction ${ }^{4}$ and bone regeneration ${ }^{5}$. However, according to cellular therapy protocols used in clinical trials, more than one million stem cells are necessary per treatment, necessitating in vitro expansion ${ }^{6}$.

Repeated passaging of cells in vitro incurs the risk of replicative senescence, which primarily occurs due to oxidation caused by free radicals and can be identified by telomere shortening and fibroblast flattening with a concurrent increase in nuclear/nucleolar size that results in stalled cell proliferation ${ }^{7}$. These phenomena limit in vitro cell expansion and might hinder their therapeutic applications ${ }^{8}$.

Antioxidants are compounds that directly or indirectly inhibit production of reactive oxygen species ${ }^{9}$ (ROS). In recent years, there is an increasing interest in finding antioxidant phytochemicals, because they can inhibit the propagation of free radical reactions ${ }^{10}$. Many essential oils have been reported as natural alternative for controlling of oxidative stress such as the essentials oils from Lippia species ${ }^{11}$.

Lippia origanoides Kunth (Verbenaceae) is an aromatic plant, popularly known in North Brazil as "erva-do-marajó" and is widely found throughout the Brazilian Amazon. The leaves are used as a condiment, as a substitute for oregano and its tea for treating gastrointestinal and respiratory diseases ${ }^{12}$. The antioxidant activity of this essential oil is attributed to the presence of phenol compounds such as thymol, carvacrol, and derivatives ${ }^{13}$.

Several biological activities have been reported for thymol. This phenolic compound plays an important role in the scavenging of free radicals such as DPPH (1,1-diphenyl2-picrylhydrazyl) and ABTS (2,2'-azino-bis3-ethylbenzthiazoline-6-sulphonic acid). In addition, at lower concentrations, it showed protective effects to cells against damage induced by the $\mathrm{H}_{2} \mathrm{O}_{2}$ radicals ${ }^{14,15}$. Thus, the aim of this study was to assess the proliferation of human ADSCs in culture medium treated with natural antioxidants present in the $L$. origanoides Kunth essential oil.

\section{Methods}

The project was approved by the Ethics in Research Committee for Human Beings, Hospital Universitário João de Barros Barreto, Belem-PA, Brazil (Number of process: 487.533).

Adipose tissue was collected from the infra-umbilical region of three patients $(27,29$, and 33 years of age; average, 29 years), without comorbidities, treated with liposuction in the private hospital. All patients signed a Free and Informed Consent Form.

\section{Liposuction}

Patients were operated on under peridural anesthesia. To collect the lipoaspirate, asepsis and antisepsis were performed in the infra-umbilical region, followed by infiltration with $0.9 \%$ saline solution with 1: 500,000 adrenalines at the demarcated site. The sample was aspirated through a syringe with a $3.5-\mathrm{mm}$ diameter cannula and decanted by gravity for 30 minutes. A total of $10 \mathrm{~mL}$ of adipose tissue was collected with partial removal of the bloody contents. 
Isolation and cultivation of MSCs from human adipose tissue

The lipoaspirate tissue $(2 \mathrm{~mL})$ was washed with $2 \mathrm{~mL}$ of phosphate-buffered saline (PBS; SigmaAldrich, St. Louis, Missouri, USA) and incubated with $200 \mathrm{U} / \mathrm{mL}$ collagenase II for 60 $\min$ at $37^{\circ} \mathrm{C}$. After incubation, the collagenase was neutralized by adding complete cultivation medium (Dulbecco's Modified Eagle's Medium (DMEM; Sigma Aldrich) supplemented with $10 \%$ fetal bovine serum (FBS; Sigma Aldrich), $3.7 \mathrm{~g} / \mathrm{L} \mathrm{NaHCO}_{3}$ (Sigma Aldrich), and $5 \mathrm{\mu g} /$ $\mathrm{mL}$ of gentamicin (Sigma Aldrich). Following centrifugation, the pellet was resuspended twice with DMEM and plated. After 24 hours, any cells still in suspension were removed and the cultivation medium was renewed. The remaining adherent cells, representing MSCs, were kept at $37^{\circ} \mathrm{C}$ in $5 \% \mathrm{CO}_{2}$ with high humidity, and the cultivation medium was changed every three days until the third passage.

\section{Cellular and histological characterization of cell differentiation}

Histology with tissue-specific dyes was used to characterize the ability of MSCs to differentiate into bone tissue, adipose tissue, and cartilage tissue.

To induce osteoblast differentiation, cells at $70 \%$ confluence were treated with osteogenic induction medium (DMEM, 0.1 $\mu \mathrm{M}$ dexamethasone (Sigma Aldrich), 50 $\mu \mathrm{M}$ ascorbic acid-2-phosphate (Sigma Aldrich), and $10^{-2} \mathrm{M} \beta$-glycerophosphate (Mallinckrodt Baker, Phillipsburg, New Jersey, USA)) and cultivated for 21 days.

To induce adipocyte differentiation, nearly confluent cells were treated with adipogenic induction medium (DMEM, $1 \mu \mathrm{M}$ dexamethasone, and $10 \mu \mathrm{M}$ insulin (Sigma Aldrich)) and cultivated for 14 days.

To induce chondrocyte differentiation, was prepared a cell solution of $1.6 \times 10^{7}$ viable cells $/ \mathrm{mL}$, and after 2 hours, cells were treated with chondrocytic induction medium (DMEM, $6.25 \mu \mathrm{g} / \mathrm{mL}$ insulin, $50 \mu \mathrm{M}$ ascorbic acid-2-phosphate, and $10 \mu \mathrm{g} / \mathrm{mL}$ TGF- $\beta 1$ (Cell Signaling Technology, Beverly, Massachusetts, USA) and cultivated for 21 days.

After cultivation, the differentiation medium was removed, and the cells were washed once with PBS. Next, cell monolayers were fixed with paraformaldehyde (Electron Microscopy Sciences) for 30 minutes and then washed twice with PBS. To detect osteoblasts, cells were stained with Alizarin Red S (Life Technologies, Carlsbad, California, USA) for 3 minutes. To detect adipocytes, cells were stained with Oil Red O (Life Technologies) for 30 minutes. To detect chondroblasts, cells were stained with Alcian Blue (Life Technologies) for 30 minutes. After staining, cells were washed three times with distilled water and analyzed by an optical microscope (911873 AXIOLAB, Ziss, Germany) - osteoblasts and chondroblasts - and by an inverted microscope (TE-DH100W, Nikon, Japan) - adipocytes.

\section{Plant collection and extraction and analysis of essential oil}

The aerial parts of $L$. origanoides were collected in the National Forest of Carajás (Parauapebas-PA, Brazil), which occurs in endemic form in that area. The botanical material was identified by comparison with an authentic voucher (MG 133.921) existing in the Herbarium of Emílio Goeldi Museum (BelemPA, Brazil). The essential oil was hydrodistilled using a Clevenger-type apparatus (Hanil Lab Tech Ltd, Incheon, Korea), dried with sodium sulfate and stored in a refrigerator at $5 \circ \mathrm{C}$. The oil was analyzed by gas chromatography coupled with mass spectrometry (GC-MS) and its volatile constituents identified by comparison with authentic standards existing in the Adams library ${ }^{16}$. The GC-MS analysis was carried on a Thermo Focus DSQ II, under the 
following conditions: DB-5ms (30 m x $0.25 \mathrm{~mm}$; $0.25 \mathrm{~mm}$ film thickness) fused-silica capillary column; programmed temperature, $60-240^{\circ} \mathrm{C}$ ( $3^{\circ} \mathrm{C} / \mathrm{min}$ ); injector temperature, 250 ㅇ; carrier gas, helium, adjusted to a linear velocity of $32 \mathrm{~cm} / \mathrm{s}$ (measured at $100^{\circ} \mathrm{C}$ ); injection type, split $(1 \mu \mathrm{L})$, from 1:1000 hexane solution; split flow was adjusted to yield a 20:1 ratio; septum sweep was a constant $10 \mathrm{ml} / \mathrm{min}$; EIMS, electron energy, $70 \mathrm{eV}$; temperature of the ion source and connection parts, $200^{\circ} \mathrm{C}$. The quantitative data regarding the volatile constituents were obtained by peak area normalization using a FOCUS GC/FID operated under similar conditions of the GC-MS, except the carrier gas, which was nitrogen. The retention index was calculated for all the volatiles constituents using a homologous series of $n$-alkanes (C8C32, Sigma-Aldrich) ${ }^{17}$.

For cell treatments, the essential oil was initially solubilized in dimethyl sulfoxide (DMSO; Sigma-Aldrich) at concentration 10.0 $\mu \mathrm{g} / \mathrm{mL}$. This stock solution was diluted to concentrations of $25.0 \mu \mathrm{g} / \mathrm{mL}, 5.0 \mu \mathrm{g} / \mathrm{mL}$ and $1.0 \mu \mathrm{g} / \mathrm{mL}$ in DMEM.

\section{MTT assay of cellular growth rate}

The 3-(4,5-dimethylthiazol-2-yl)-2,5diphenyltetrazolium bromide (MTT) assay was performed during the first cellular passage (P1) to determine cell viability in the treatment and control groups. Cells were plated at a concentration of $3 \times 10^{3}$ cells/well in a 96well plate (TPP, Trasadingen, Schaffhausen, Switzerland) and incubated with different essential oil concentrations $(1.0 \mu \mathrm{g} / \mathrm{mL}, 5.0 \mu \mathrm{g} /$ $\mathrm{mL}$, and $25.0 \mu \mathrm{g} / \mathrm{mL}$ ) in triplicate. After the third day of cell cultivation, the culture medium was replaced with $100 \mu \mathrm{L}$ of $5 \mathrm{mg} / \mathrm{mL}$ MTT solution in $900 \mu \mathrm{L}$ in DMEM (without FBS). After 3 hours incubation at $37^{\circ} \mathrm{C}$, the MTT solution was removed and $100 \mu \mathrm{L}$ of DMSO was added to each well and the plate was shaken for 10 minutes. The percentage of cellular growth rate (GR \%) was based on absorbance at 490 $\mathrm{nm}\left(\mathrm{A}_{490}\right)$ measured in spectrophotometer UV/ VIS and calculated according to the following equation.

\section{Cell counting}

At P2 and P3, $4 \times 10^{4}$ cells $/ \mathrm{mL}$ were plated in two $35-\mathrm{mm}$ plates, one with only DMEM and the other with $1.0 \mu \mathrm{g} / \mathrm{mL}$ essential oil (the concentration with the highest rate of cell proliferation). After 72 hours, cells were resuspended with trypsin and $1 \mu \mathrm{l}$ of cell were placed and counted in a Neubauer Chamber. All the cells within each medium square were counted using $x 4$ objective and multiplied for a correction factor of $10^{4}$ (cell/ml).

\section{Statistical analysis}

Statistical analyses were performed using the GraphPad Prism version 5.0 (GraphPad Software, California, USA). A oneway ANOVA test was performed to assess the rate of cell proliferation using values obtained from the MTT assay followed by Tukey's post hoc test. Values of $p \leq 0.05$ were considered significant.

\section{Results}

Characterization of tissues differentiated from ASCs are shown in Figure 1. Figure $1 \mathrm{~A}-\mathrm{C}$ exhibit the control of each histological characterization. Numerous fat drops formed in the adipocytic lineage (Figure 1D). We observed glycosaminoglycan accumulation in the chondrogenic lineage, as revealed by Alcian Blue (Figure $1 \mathrm{E}$ ). The osteogenic lineage stained with Alizarin Red $\mathrm{S}$, indicating an accumulation of extracellular calcium (Figure 1F). 

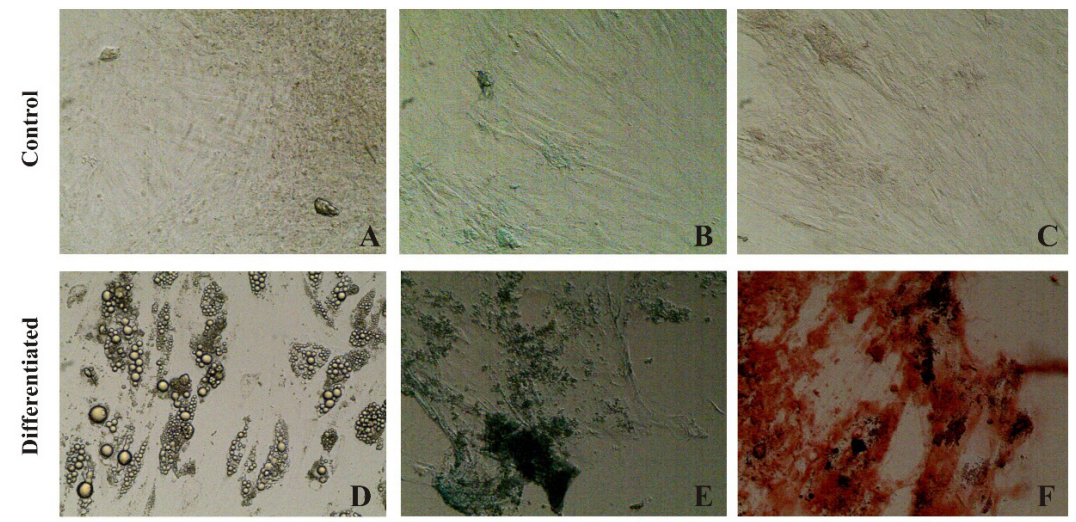

Figure 1 - (A-C) ASCs cultured control. (D) Adipogenic differentiation of the ASCs. Fat vesicles detected by staining with Oil Red $\mathrm{O}$ after 14 days of induction. (E) Chondrogenic differentiation of ASCs stained with Alcian Blue after 21 days of induction. (F) Osteogenic differentiation of ASCs stained with Alizarin Red S after 21 days of induction.

The proliferation results obtained by the MTT assay are shown in Figure 2. The absorbance values passed the Normality Test $(p=0.722)$ and the Equality of Variance Test ( $p=0.24)$ in all treatments. Compared with the control, cell proliferation was higher in the three experimental groups treated with essential oil from $L$. origanoides $(p=0.0008)$. Cell proliferation did not significantly differ between the three experimental groups.

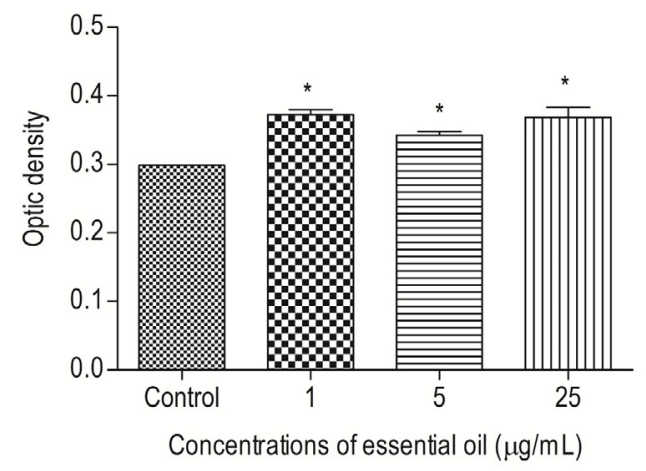

Figure 2 - Averages and standard deviation for absorbance related to cell proliferation (MTT assay) of stem cells derived from human adipose tissue cultivated with essential oil of Lippia origanoides in the $1^{\text {st }}$ passage. $*$ indicates a significant difference $(p<0.05)$ in relation to the control group.

The proliferation rates cells treated with $1.0 \mu \mathrm{g} / \mathrm{mL}, 5.0 \mu \mathrm{g} / \mathrm{mL}$, and $25.0 \mu \mathrm{g} /$
$\mathrm{mL}$ of essential oil were $24.8 \%, 14.7 \%$, and $16.3 \%$ greater than control cells, respectively (Figure 3). At P2, control cells and cells treated with $1 \mu \mathrm{g} / \mathrm{mL}$ of essential oil were plated at a concentration of $4 \times 10^{4}$ cells $/ \mathrm{mL}$. After $72 \mathrm{~h}$ of cultivation and subsequent trypsin treatment, both groups had a concentration of $18 \times 10^{4}$ cells/mL (Figure 4). At P3, the cells were again plated at $4 \times 10^{4}$ cells $/ \mathrm{mL}$ However, in this case the concentration of the essential oil-treated cells was approximately $43 \%$ greater than that of the control cells after cultivation and enzymatic digestion $\left(20 \times 10^{4}\right.$ cells $/ \mathrm{mL}$ vs. $14 \times 10^{4}$ cells/mL) (Figure 5).

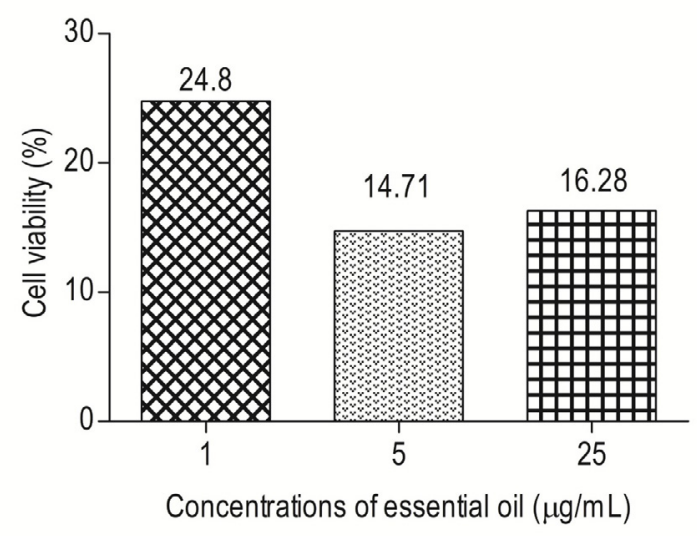

Figure 3 - Growth rate of stem cells derived from human adipose tissue of each group treated (1.5 and $25 \mu \mathrm{g} / \mathrm{mL}$ ) in relation to the control in the $1^{\text {st }}$ passage. 


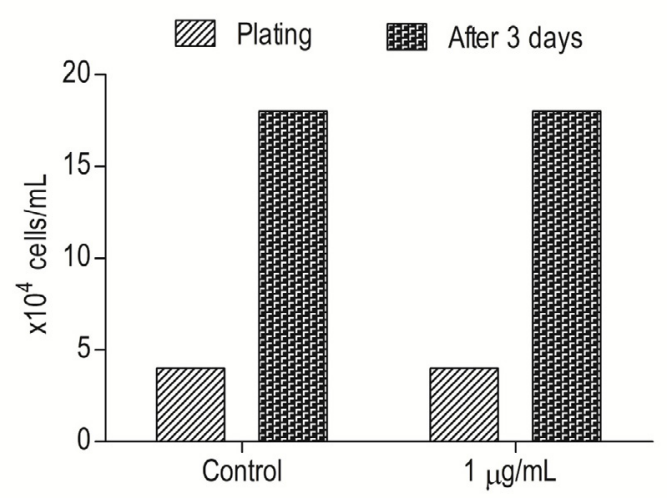

Figure 4 - Effect of the essential oil of Lippia origanoides $(1 \mu \mathrm{g} / \mathrm{mL})$ on multiplication of stem cells derived from human adipose tissue in the $2^{\text {nd }}$ passage after 3 days of cultivation.

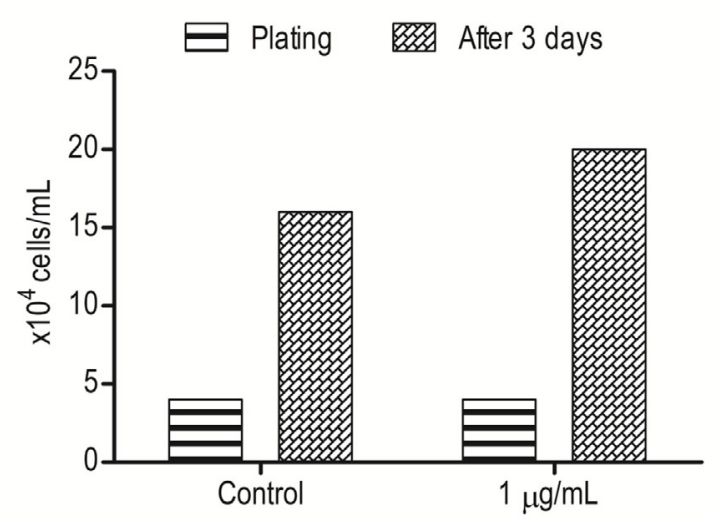

Figure 5 - Effect of the essential oil of Lippia origanoides $(1 \mu \mathrm{g} / \mathrm{mL})$ on multiplication of stem cells derived from human adipose tissue in the $3^{\text {rd }}$ passage after 3 days of cultivation.

The dried aerial parts of $L$. origanoides provide oil yield of $3.3 \%$. Individual components were identified by comparison of both mass spectrum and GC retention data with authentic compounds, which were previously analyzed and stored in the data system. Seventeen volatile components were identified in the oil, comprising nearly $100 \%$ of its composition (Table 1). Thymol (88.2\%) was the main constituent, followed by $p$-cymene $(6.4 \%)$, its biogenetic precursor.
Table 1 - Chemical composition of the essential oil of Lippia origanoides.

\begin{tabular}{|c|c|c|c|}
\hline Compound & $\mathbf{R} \mathbf{l}^{\mathbf{a}}$ & $\mathbf{R}^{\mathbf{b}}$ & Oilc (\%) \\
\hline$\alpha$-Thujene & 916 & 924 & 0.2 \\
\hline$\alpha$-Pinene & 922 & 932 & 0.3 \\
\hline$\beta$-Pinene & 966 & 974 & 0.1 \\
\hline$\alpha$-Phellandrene & 999 & 1002 & 0.1 \\
\hline$p$-Cymene & 1014 & 1020 & 6.4 \\
\hline$E$ - $\beta$-Ocimene & 1034 & 1044 & 1.1 \\
\hline Terpinolene & 1074 & 1086 & 0.1 \\
\hline Linalool & 1088 & 1095 & 0.5 \\
\hline Umbellulone & 1158 & 1167 & 0.1 \\
\hline Terpinen-4-ol & 1168 & 1174 & 0.3 \\
\hline Thymol, methyl ether & 1217 & 1232 & 0.1 \\
\hline Thymol & 1279 & 1289 & 88.2 \\
\hline Carvacrol & 1285 & 1298 & 1.0 \\
\hline$\alpha$-Copaene & 1360 & 1374 & 0.1 \\
\hline$\beta$-Caryophyllene & 1402 & 1417 & 0.3 \\
\hline$\alpha$-Humulene & 1438 & 1452 & 0.7 \\
\hline$\delta$-Amorphene & 1500 & 1511 & 0.1 \\
\hline \multicolumn{2}{|c|}{ Monoterpene hydrocarbons } & & 8.3 \\
\hline \multicolumn{2}{|c|}{ Oxygenated monoterpene } & & 90.2 \\
\hline \multicolumn{2}{|c|}{ Sesquiterpene hydrocarbons } & & 1.2 \\
\hline \multicolumn{2}{|l|}{ Total } & & 99.7 \\
\hline
\end{tabular}

a Retention index calculated using the homologous series of $n$-alcanes; 'betention index in the literature (ADAMS, 2007); cPercentage of compounds obtained by integrating the area in the flame ionization detector.

\section{Discussion}

Essential oils are one among the most valuable plant products used in medicine and complementary treatment strategies. However, this is the first study, which reports the use of essential oil from $L$. origanoides as a supplement in human stem cell culture.

Our results indicated that the cultivation medium supplemented with essential oil showed a proliferative effect, with the most significant result found at P3. The principal constituent of the oil of $L$. origanoides using in this study was thymol (88.2\%), It is classified chemically as monoterpene. This compound 
exhibit different mechanisms of action because the presence of a phenolic ring in its structure enhance the antioxidant activity due to its ability for scavenging free radicals, donation of hydrogen atoms or electron, or chelation of metal cations ${ }^{16}$. We have hypothesized that the cell proliferation was due to Thymol's cytoprotective effect, as another monoterpene (1,8-Cineole, Camphor, $\alpha$-Pinene and $\beta$-pinene) presents in oil of Salvia lavandulifolia Vahl showed a protective effect in cultured human astrocytoma too ${ }^{18}$.

Tavakolinejad et al. ${ }^{19}$ cultivated human adipose tissue-derived stem cells in medium containing platelet-rich plasma (PRP) instead of FBS or L. origanoides. Cellular growth rates in the work of them (40\%) were similar to this study at P3 (40 vs. 43\%). However, even automated methods for obtaining PRP can result in variable product quality. On the other hand, essential oil from $L$. origanoides function as antioxidants, allowing extended cell cultivation in vitro without probable cell damage.

Cells become senescent with increasing passage number, thus reducing their growth ${ }^{8}$. Previous studies have found stem cells derived from senescent human adipose tissue at P2 based on a $\beta$-galactosidase assay. By P5, almost $20 \%$ of cells were derived from senescent tissue $^{20}$. In our study, the antioxidant function of essential oil from Lippia origanoides may have inhibited the oxidation of free radicals produced in vitro, enabling cell growth even at P3. Future studies should be done to verify the maximum passage number that benefits from essential oil-treatment, as well as examine other basic cell characteristics such as cell senescence and telomere shortening.

\section{Conclusions}

Supplementing culture medium with essential oil of Lippia origanoides increased the proliferation of stem cells derived from human adipose tissue in vitro, especially at later cell passages. This essential oil has the potential to become a cheap and efficient mean for optimally expanding adult stem cells in vitro for cell therapy.

\section{References}

1. Zuk PA, Zhu M, Mizuno $H$, Huang J, Futrell JW, Katz AJ, Benhaim P, Lorenz HP, Hedrick $\mathrm{MH}$. Multilineage cells from human adipose tissue: implications for cell-based therapies. Tissue Eng. 2001;7:211-28. PMID: 11304456.

2. Zhu T, Liu T, Song K, Fan X, Ma X, Cui Z. Adipose-derived stem cell: a better stem cell than BMSC. Cell Biochem Funct. 2008;26:664-75. doi: 10.1002/cbf.1488.

3. Nakamuta JS, Danoviz ME, Marques FL, dos Santos L, Becker C, Gonçalves GA, Vassallo PF, Schettert IT, Tucci PJ, Krieger JE. Cell therapy attenuates cardiac dysfunction post myocardial infarction: effect of timing, routes of injection and a fibrin scaffold. PLoS One. 2009;4:1-10. doi: 10.1371/journal. pone.0006005.

4. Houtgraaf JH, den Dekker WK, van Dalen $B M$, Springeling $T$, de Jong R, van Geuns RJ, Geleijnse ML, Fernandez-Aviles F, Zijlsta F, Serruys PW, Duckers HJ. First experience in humans using adipose tissue-derived regenerative cells in the treatment of patients with ST-segment elevation myocardial infarction. J Am Coll Cardiol. 2012; 59:53940. doi: 10.1016/j.jacc.2011.09.065.

5. Li W, Liu Y, Zhang P, Tang Y, Zhou M, Jiang W, Zhang $X$, Wu G, Zhou Y. Tissue-engineered bone immobilized with human adipose stem cells-derived exosomes promotes bone regeneration. ACS Appl Mater Interfaces. 2018;10:5240-54. doi: 10.1021/ acsami.7b17620.

6. Cheng AKL, Reuveny S, Oh SKW. Application of human mesenchymal and pluripotent stem cell microcarrier cultures in cellular therapy: achievements and future direction. Biotechnol Adv. 2013;31:1032-46. doi: 10.1016/j.biotechadv.2013.03.006.

7. Parrinello S, Samper E, Krtolia A, Goldstein J, Melov S, Campisi J. Oxygen sensitivity severely limits the replicative lifespan of murine fibroblasts. Nat Cell Biol. 2003;5:7417. doi: $10.1038 / \mathrm{ncb} 1024$.

8. Wagner W, Horn $P$, Castoldi M, Diehlmann A, Bork S, Saffrich R, Benes V, Blake J, Pfister $S$, Eckstein V, Ho AD. Replicative senescence of mesenchymal stem cells: a continuous and organized process. PLoS One. 2008;3:1- 
12. doi: 10.1371/journal.pone.0002213.

9. Khlebnikov AI, Schepetkin IA, Domina NG, Kirpotina LN, Quinn MT. Improved quantitative structure-activity relationship models to predict antioxidant activity of flavonoids in chemical, enzymatic, and cellular systems. Bioorg Med Chem. 2007;15:1749-70. doi: 10.1016/j. bmc.2006.11.037.

10.Carocho M, Ferreira ISFR. A review on antioxidants, prooxidants and related controversy: Natural and synthetic compounds, screening and analysis methodologies and future perspectives. Food Chem Toxicol. 2013;51:15-25. doi: 10.1016/j.fct.2012.09.021.

11.Damasceno EIT, Silva JKR, Andrade EHA, Sousa PJC, Maia JGS. Antioxidant capacity and larvicidal activity of essential oil and extracts from Lippia grandis. Rev Bras Farmacogn. 2011;21:78-85. doi: 10.1371/ journal.pone.0175598.

12.Maia JGS, Zoghbi MGB, Andrade EHA. Plantas aromáticas da Amazônia e seus óleos essenciais. Belém (Pará): Museu Paraense Emílio Goeldi; c2001.

13. Ribeiro AC, Andrade EHA, Salimena FRG, Maia JGS. Circadian and seasonal study of the cinnamate chemotype from Lippia origanoides Kunth. Biochem Syst Ecol. 2014;55:249-59. doi: 10.1016/j. bse.2014.03.014.

14.da Silva APS, Silva NF, Andrade EHA, Setzer TGWN, Maia JGS, da Silva JKR. Tyrosinase inhibitory activity, molecular docking studies and antioxidant potential of chemotypes of Lippia origanoides (Verbenaceae) essential oils. PLoS One. 2017;12:1-17. doi: 10.1371/ journal.pone.0175598.
15.Llana-Ruiz-Cabello $M$, Gutiérrez-Praena $D$, Puerto $M$, Pichardo $S$, Jos $A$, Cameán AM. In vitro pro-oxidant/antioxidant role of carvacrol, thymol and their mixture in the intestinal Caco-2 cell line. Toxicol In Vitro. 2015;29:647-56. doi: 10.1016/j. tiv.2015.02.006.

16.Adams, RP. Identification of essential oil components by gas chromatography/mass spectrometry. 4ed. Carol Stream (Illinois): Allured Publishing Corporation; 2007.

17.Da Silva JKR, Pinto LC, Burbano RMR, Montenegro RC, Guimarães EF, Andrade EHA, Maia JGS. Essential oils of Amazon Piper species and their cytotoxic, antifungal, antioxidant and anti-cholinesterase activities. Ind Crops Prod. 2014;58:55-60. doi: 10.1016/j.indcrop.2014.04.006.

18.Martínez MP, González-Burgos E, Carretero ME, Gómez-Serranillos MP. Influence of phenological stage on chemical composition and antioxidant activity of Salvia lavandulifolia Vahl. essential oils. Ind Crops Prod. 2014;53:71-7. doi: 10.1016/j. indcrop.2013.12.024.

19.Tavakolinejad S, Khosravi M, Mashkani B, Bideskan AE, Mossavi NS, Parizadeh MR, Alamdari $\mathrm{DH}$. The effect of human plateletrich plasma on adipose-derived stem cell proliferation and osteogenic differentiation. Iran Biomed J. 2014;18:151-7. doi: 10.6091/ ibj.1301.2014.

20.Estrada JC, Benguría A, Dopazo A, Roche E, Carrera-Quintanar L, Pérez RA, Enríquez JA, Torres R, Ramírez JC, Samper E, Bernad A. Human mesenchymal stem cell-replicative senescence and oxidative stress are closely linked to aneuploidy. Cell Death Dis. 2013;691:1-13. doi: 10.1038/ cddis.2013.211.

\section{Correspondence:}

Felipe Nunes Brito

Rua Borges Lagoa, 71/114

040380-030 São Paulo - SP Brasil

Tel.: (55 11)98181-5928

felipnunes@hotmail.com

Received: Jan 10, 2018

Review: Mar 08, 2018

Accepted: Apr 11, 2018
Conflict of interest: none

Financial source: $\mathrm{CNPq}$

\begin{abstract}
${ }^{1}$ Research performed at In Vitro Fertilization Laboratory, Department of Biological Sciences, Universidade Federal do Pará (UFPA), BelemPA, Brazil.
\end{abstract}

